\title{
PENGARUH MOTIVASI TERHADAP KINERJA AUDITOR (Studi Empiris Pada Inspektorat Provinsi Sulawesi Selatan)
}

\author{
Siti Nur Reskiyawati Said \\ STIE Tri Dharma Nusantara Makassar \\ Email : st.kiyasaid@gmail.com
}

\begin{abstract}
Abstrak
Tujuan dari penelitian ini adalah untuk memberikan ulasan serta memperoleh bukti secara empiris tentang pengaruh motivasi terhadap kinerja auditor. Penelitian ini menggunakan penelitian penjelasan (explanation research) dengan pendekatan kuantitaif yang diperoleh dari kuesioner dan diukur dengan menggunakan skala ordinal. Populasi dalam penelitian ini adalah auditor lnspektorat Daerah Pemerintah Provinsi Sulawesi Selatan sebanyak 55 auditor. Metode yang digunakan dalam penelitian ini adalah metode sensus. Data dianalisis dengan menggunakan software SPSS versi 22. Hasil penelitian menunjukkan bahwa motivasi berpengaruh positif dan signifikan terhadap kinerja auditor.
\end{abstract}

Kata kunci: Motivasi, kinerja auditor

\section{Abstract}

This study was aimed to provide a review and finding empirical evidence about the effect of motivation on auditor performance. This research uses explanatory research with a quantitative approach obtained from the questionnaire and measured using the ordinal scale. The population in this study was the Regional Inspectorate Auditors of the South Sulawesi Provincial Government of 55 auditors. The method used in this study is the census method. Data were analyzed using SPSS software version 22. The results showed that motivation had a positive and significant effect on auditor performance.

Keywords: Motivation, and auditor performance

\section{PENDAHULUAN}

Auditor adalah akuntan publik yang memberikan jasa kepada auditan untuk memeriksa laporan keuangan agar bebas dari salah saji (Mulyadi, 2013). Auditor harus bertanggung jawab terhadap hasil audit dengan memenuhi standar audit dengan berorientasi terhadap kepentingan publik, hal ini karena adanya harapan masyarakat agar tercipta praktik akuntansi yang sehat, kredibel, dan dapat dipercaya. Arens et al. (2008) menyebutkan bahwa auditor yang mempertahankan objektivitasnya akan bertindak adil tanpa dipegaruhi tekanan dan permintaan pihak tertentu atau kepentingan pribadinya.

Inspektorat Provinsi adalah aparat pengawas fungsional yang berada dibawah dan bertanggung jawab terhadap gubernur. Tugas pokok dan fungsi inspektorat provinsi Sulawesi selatan ditetapkan dalam peraturan gubernur sulawesi selatan nomor 31 tahun 2008 tentang tugas pokok, fungsi dan rincian tugas jabatan struktural inspektorat provinsi sulawesi selatan. Tugas pokok inspektorat yaitu melakukan pengawasan terhadap pelaksanaan urusan pemerintah didaerah provinsi, pelaksanaan pembinaan dan pengawasan atas penyelenggaraan urusan pemerintahan daerah kabupaten/kota dan pelaksanaan urusan pemerintah didaerah 
kabupaten/kota. Sedangkan fungsi inspektorat yaitu menyusun perencanaan program pengawasan, melakukan perumusan kebijakan dan fasilitas pengawasan, melaksanakan pemeriksaan, pengusutan, pengujian dan penilaian tugas pengawasan, serta penyelenggaraan tugas lain yang diberikan oleh gubernur sesuai dengan bidang tugas dan fungsinya.

Berbagai tindakan yang melanggar aturan terkait kurangnya pengawasan kerap terjadi pada instansi pemerintahan. Sebagai contoh, kasus tindak pidana korupsi terkait pengadaan barang dan jasa serta anggaran makan dan minum yang dilakukan oleh kepala Badan Pengelolaan Keuangan dan Aset Daerah (BPKAD) kota Makassar Erwin Syafruddin Haija. Hal ini dapat merugikan keuangan Negara sebesar Rp. 313.315.161 (tiga ratus tiga belas juta tiga ratus lima belas ribu seratus enam puluh satu rupiah). Fakta berikutnya adalah adanya tindak pidana korupsi pengadaan barang persediaan sanggar kerajinan lorong-lorong kota Makassar pada Dinas Koperasi dan UKM Kota Makassar yang dilakukan oleh mantan kepala Dinas Koperasi dan UKM Kota Makassar Gani Sirman dan M Enra Efni selaku kepala bidang unit kegiatan di Dinas Koperasi dan UKM. Ditemukan kerugian negara yaitu Rp. 380.128.801.74 melalui APBD Makassar 2016 dengan realisasi pembayaran barang persediaan sebesar Rp 873.275.929.00, sedangkan nilai barang persediaan yang diterima sanggar setelah pajak adalah Rp. 493.147.127.26. (sipp.pn-makassar.go.id). Jika inspektorat telah menjalankan tugas dan fungsinya dengan baik maka akan tercipta kondisi yang efektif dan efisien dalam hal pengawasan.

Praktik kecurangan dalam hal laporan keuangan dapat menjadi faktor kehancuran ekonomi negara dalam skala besar karena laporan audit yang seharusnya menjadi bukti kebenaran menjadi tidak berguna karena disalah gunakan untuk membela pihak-pihak yang bersalah. Sementara itu, Robbins dan Judge (2008) mengemukakan bahwa terdapat tiga konsep yang dapat diterapkan untuk mendukung timbulnya akuntabilitas yang secara tidak langsung berpengaruh terhadap kinerja auditor, yaitu motivasi, pengabdian terhadap profesi, dan kewajiban sosial. dapat menjaga kepercayaan masyarakat terhadap profesi yang diemban.

Menurut Hariandja (2009) motivasi adalah faktor-faktor yang mengarahkan dan mendorong perilaku atau keinginan seseorang untuk melakukan suatu kegiatan yang dinyatakan dalam bentuk usaha yang keras dan lemah. Sedangkan Robbins dan Judge (2008) menyatakan bahwa motivasi merupakan proses yang menjelaskan intensitas, arah dan juga ketekunan seseorang untuk mencapai tujuannya.

Penelitian mengenai pengaruh motivasi terhadap kinerja auditor telah beberapa kali dilakukan di Indonesia. Diantaranya, penelitian dari Azhar (2013), Panjaitan dan Jatmiko (2014), Permana (2016), Marita dan Gultom (2018), Ketiganya meneliti tentang pengaruh 
motivasi terhadap kinerja auditor. Perbedaan penelitian pada obyek yang diteliti, Azhar meneliti pada kantor akuntan publik Pekanbaru (2013), Panjaitan dan Jatmiko (2014) meneliti pada kantor akuntan publik di DKI Jakarta, Permana (2016) meneliti pada Badan Pengawas Keuangan dan Pembangunan, sementara Marita dan Gultom (2018) meneliti pada PT Perkebunan Nusantara IV Medan

Hasil penelitian dari Panjaitan dan Jatmiko (2014), Permana (2016), serta Marita dan Gultom (2018), menunjukkan bahwa motivasi berpengaruh signifikan terhadap kinerja atau kualitas auditor. Hasil ini bertentangan dengan penelitian Azhar (2013) yang menemukan bahwa motivasi tidak berpengaruh terhadap kinerja auditor. Hal ini dikarenakan ada atau tidaknya atau besar atau tidaknya pengaruh motivasi yang diberikan seperti dukungan,

Kinerja auditor menurut Mulyadi (2008) adalah akuntan publik yang melaksanakan pemeriksaan (examination) secara obyektif atas laporan keuangan suatu perusahaan atau organisasi yang bertujuan untuk menentukan apakah laporan keuangan telah disajikan secara wajar sesuai dengan prinsip akuntan yang berlaku umum dalam semua hal yang material, posisi keuangan dan hasil usaha perusahaan dan dalam melaksanakannya auditor harus mematuhi kode etik Akuntan Publik Indonesia dan Standar Auditing.

Goal Setting Theory yang dikemukakan oleh Locke (1978) menjelaskan hubungan antara tujuan yang ditetapkan dengan prestasi kerja (kinerja), konsep dasar teori ini adalah seseorang yang memahami tujuan (apa yang diharapkan organisasi kepadanya) akan mempengaruhi perilaku kerjanya. Teori ini menyatakan bahwa perilaku individu diatur oleh ide (pemikiran) dan niat seseorang. Sasaran dapat dipandang sebagai tujuan atau tingkat kinerja yang ingin dicapai oleh individu. Goal setting theory mengisyaratkan bahwa seorang individu berkomitmen pada tujuan (Robbins, 2008). Jika seorang individu berkomitmen untuk mencapai tujuannya, maka hal ini akan mempengaruhi tindakannya dan mempengaruhi konsenkuensi kinerjanya.

Berdasarkan uraian tersebut diatas, maka penelitian ini diberi judul Pengaruh Motivasi terhadap Kinerja Auditor, karena motivasi dianggap sebagai salah satu konsep yang dapat diterapkan untuk mendukung timbulnya akuntabilitas yang secara tidak langsung berpengaruh terhadap kinerja auditor.

\section{TINJAUAN PUSTAKA}

\section{Goal Setting Theory}

Teori yang dikemukakan oleh Locke (1978) menjelaskan hubungan antara tujuan yang ditetapkan dengan prestasi kerja (kinerja). Konsep dasar teori ini adalah seseorang yang 
memahami tujuan (apa yang diharapkan organisasi kepadanya) akan memengaruhi perilaku kerjanya. Teori ini menyatakan bahwa perilaku individu diatur oleh ide (pemikiran) dan niat seseorang. Sasaran dapat dipandang sebagai tujuan atau tingkat kinerja yang ingin dicapai oleh individu. Jika seorang individu berkomitmen untuk mencapai tujuannya maka hal ini akan memengaruhi tindakannya dan memengaruhi konsekuensi kinerjanya.

Menurut teori ini salah satu dari karakteristik perilaku yang mempunyai tujuan umum diamati ialah bahwa perilaku tersebut terus berlangsung sampai periaku itu mencapai penyelesaiannya, sekali seseorang mulai sesuatu (seperti suatu pekerjaan, sebuah proyek baru), ia terus mendesak sampai tujuan tercapai. Teori ini juga menyatakan bahwa perilaku individu diatur oleh ide (pemikiran) dan niat seseorang. Sasaran dapat dipandang sebagaii tujuan atau tingkat kerja yang ingin dicapai oleh individu. Goal setting theory mengisyaratkan bahwa seorang indlividu berkomitmen pada tujuan (Robbins, 2008). Jika seorang individu berkomitmen untuk mencapai tujuannya, maka hal ini akan memengaruhi mempengaruhi tindakannya dan mempengaruhi konsenkuensi kinerjanya.

Teori ini mengasumsikan manusia sebagai individu yang berfikir (thinking individual) yang berusaha mencapai tujuan tertentu. Teori ini memfokuskan pada proses penetapan tujuan itu sendiri. Kecenderungan manusia untuk menetapkan dan berusaha mencapai suatu tujuan akan terjadi jika manusia memahami dan menerima tujuan tertentu yang telah ditetapkan.

\section{Motivasi Kerja.}

Menurut Samsuddin (2010:281) mengemukakan bahwa motivasi adalah proses yang mempengaruhi atau mendorong dari luar terhadap seseorang atau kelompok kerja agar mereka mau melaksanakan sesuatu yang telah ditetapkan, sedangkan menurut Sondang (2009:102) menyatakan bahwa motivasi merupakan daya dorong bagi seseorang untuk memberikan kontribusi yang sebesar mungkin demi keberhasilan organisasi mencapai tujuannya. Selanjutnya Robbins dan Judge (2008) menyatakan bahwa motivasi merupakan proses yang menjelaskan intensitas, arah dan juga ketekunan seseorang untuk mencapai tujuannya.

Menurut Mangkunegara (2014) motivasi yaitu produktivitas seseorang sangat ditentukan oleh "virus mental" yang ada pada dirinya. Virus mental adalah kondisi jiwa yang mendorong seseorang untuk mampu mencapai prestasi yang maksimal. Virus mental yang dimaksud terdiri dari tiga dorongan kebutuhan, yaitu; 1). Kebutuhan untuk berprestasi, merupakan kebutuhan untuk mencapai sukses, yang diukur berdasarkan standar kesempatan dalam diri seseorang, 2). Kebutuhan berafiliasi, merupakan kebutuhan akan kehangatan dan sokongan dalam hubungannya dengan orang lain, 3). Kebutuhan kekuatan, merupakan 
kebutuhan untuk menguasai dan mempengaruhi situasi orang lain agar menjadi dominan atau pengontrol

\section{Kinerja Auditor}

Keberhasilan manajemen didalam suatu organisasi sangat bergantung pada kinerja sumber daya manusianya. Wibowo (2014) menyatakan bahwa kinerja adalah hasil yang dicapai atas pekerjaan yang dilakukan. Kinerja adalah tentang apa yang dikerjakan dan bagaimana cara mengerjakannya. Sedangkan, Mangkunegara (2014) menjelaskan bahwa kinerja berasal dari kata job performance (prestasi kerja) atau actual performance (prestasi sesungguhnya yang dicapai oleh seseorang). Jadi kinerja merupakan hasil kerja yang dicapai baik dari segi kualitas dan kuantitas atas pelaksanaan tugas dan tanggung jawab yang dilakukan oleh seorang karyawan.

Moeheriono (2012) menjelaskan kinerja atau performance merupakan gambaran mengenai tingkat pencapaian pelaksanaan suatu program kegiatan atau kebijakan dalam mewujudkan sasaran tujuan, visi, dan misi organisasi yang dituangkan melalui perencanaan strategis suatu organisasi. Selanjutnya, Wirawan (2009) menyebutkan bahwa kinerja merupakan singkatan dari kinetika energi kerja yang padanannya dalam bahasa inggris adalah performance. Kinerja adalah keluaran yang dihasilkan oleh fungsi-fungsi atau indikatorindikator suatu pekerjaan atau suatu profesi dalam waktu tertentu. Sedangkan Akbar (2015) menyatakan bahwa kinerja auditor adalah hasil pencapaian seorang auditor dalam melaksanakan tugas-tugas yang diberikan kepadanya yang didasarkan atas kecakapan, pengalaman, dan kesungguhan waktu yang diukur dengan mempertimbangkan kuantitas, kualitas, dan ketepatan waktu.

Tujuan dari pengukuran kinerja adalah untuk mengetahui apakah hasil kerja telah sesuai dengan apa yang diharapkan. Wibowo (2014) menjelaskan bahwa pengukuran kinerja dapat dilakukan dengan beberapa cara yaitu: (1) Menetapkan standar kinerja sehingga dapat diperbandingkan; (2) Menghindari konsekuensi dari rendahnya kualitas; (3) Mempertimbangkan penggunaan sumber daya; dan Menentukan apa yang perlu menjadi prioritas serta mengedepankan kualitas.

Kinerja dibedakan menjadi dua bagian yaitu kinerja individu dan kinerja organisasi. Mangkunegara (2009) menjelaskan bahwa kinerja individu adalah hasil kerja karyawan baik dari segi kualitas ataupun kuantitas yang diukur berdasarkan standar kerja yang telah ditetapkan. Adanya upaya kerja (work effort) serta dukungan yang diberikan oleh organisasi menjadi faktor yang mendukung agar individu bisa memberikan hasil kerja yang maksimal 
sehingga apa yang menjadi tujuan organisasi bisa tercapai. Lebih lanjut Mangkunegara (2009) menyetujui gagasan dari teori konvergensi William Louis Stern bahwa faktor-faktor yang menjadi penentu kinerja individu ialah faktor internal (individu) dan faktor eksternal (lingkungan kerja organisasi) Sementara, kinerja organisasi ialah kombinasi dari kinerja individu dan kinerja organisasi.

Secara spesifik, Mangkunegara (2009) menyatakan ada tiga faktor yang mempengaruhi kinerja (Performance), yaitu (1) faktor individual yang terdiri dari: kemampuan dan keahlian, latar belakang, demografi, (2) faktor psikologis yang terdiri dari persepsi, attitude, personality, pembelajaran, motivasi, (3) faktor organisasi yang terdiri dari sumber daya, kepemimpinan, penghargaan, struktur, Job Design.

\section{METODE PENELITIAN}

Penelitian ini akan dilakukan di Inspektorat Provinsi Sulawesi Selatan yang beralamat di Jln. Andi Pangerang Pettarani No. 100. Penelitian ini akan dilakukan kurang lebih 1 bulan. Waktu ini digunakan untuk memperoleh data dan melakukan analisis data penelitian. populasi dalam penelitian ini sebanyak 55 orang dengan rincian auditor auditor madya 27 orang, auditor muda 22 orang, auditor kepegawaian madya 6 orang. Metode yang digunakan dalam penelitian ini adalah metode sensus yang diperoleh dari penyebaran kuesioner kepada auditor yang berisikan variabel-variabel yang berkaitan dengan subyek penelitian. Kuesioner diisi dengan skala ordinal dengan mengukur sikap terhadap pertanyaan yang diajukan.

\section{HASIL PENELITIAN DAN PEMBAHASAN}

\section{Karakteristik Responden}

Karakteristik responden dalam penelitian ini meliputi usia, jenis kelamin, tingkat pendidikan, dan lamanya bekerja pada Inspektorat Provinsi Sulawesi Selatan. Pengukuran tersebut dapat dilakukan melalui data yang diperoleh dari kuesioner yang kembali. Tabel 1 menunjukkan karakteristik responden berdasarkan usia, jenis kelamin, tingkat pendidikan, dan lama bekerja auditor internal pada Inspektorat Provinsi Sulawesi Selatan.

Tabel 1. Demografi Responden

\begin{tabular}{|c|c|c|c|c|}
\hline No & Karakteristik & Kriteria & $\begin{array}{c}\text { Frekuensi } \\
\text { (Orang) }\end{array}$ & $\begin{array}{c}\text { Presentase } \\
(\%)\end{array}$ \\
\hline 1 & Jenis Kelamin & Laki-laki & 24 & $53,3 \%$ \\
& & Perempuan & 21 & $46,7 \%$ \\
\hline 2 & Umur & $26-35$ tahun & 2 & $4,4 \%$ \\
& & $36-45$ tahun & 21 & $46,7 \%$ \\
& & $46-55$ tahun & 19 & $42,2 \%$
\end{tabular}




\begin{tabular}{|c|c|c|c|c|} 
& & $>55$ tahun & 3 & $6,7 \%$ \\
\hline 3 & Pendidikan & Sarjana (S1) & \multicolumn{2}{|c|}{8} \\
& & Magister (S2) & 37 & $17,8 \%$ \\
\hline 4 & Masa Kerja & 1-5 Tahun & 3 & $6,7 \%$ \\
& & 6-10 Tahun & 11 & $24,4 \%$ \\
& & $>10$ Tahun & 31 & $68,9 \%$ \\
\hline
\end{tabular}

Sumber: Data Primer diolah, 2019

Responden dalam penelitian ini adalah 45 orang yang terdiri dari 21 orang perempuan atau $46,7 \%$, sedangkan 53,3\% atau 24 laki-laki. Jika melihat pendidikan terakhir, responden berpendidikan sarjana sebanyak $17,8 \%$ atau 8 orang sedangkan responden yang berpendidikan magister sebanyak $82,2 \%$ atau 37 orang. Hal ini menunjukkan bahwa responden yang terpilih dalam penelitian ini memiliki tingkat pendidikan yang bervariasi dan cukup tinggi sehingga dianngap cukup mampu untuk memahami isi dari kuesioner yang diberikan.

Berdasarkan umur dari 45 responden yang terpilih, dapat dilihat bahwa mayoritas responden berusia 36 sampai 45 tahun yakni sebanyak 21 responden atau 46,7\%. Hal ini menunjukkan bahwa responden dalam usia yang produktif. Dengan demikian dapat diasumsikan bahwa proses pengambilan keputusan dalam menanggapi pertanyaan yang ada pada kuesioner dapat dipercaya.

Berdasarkan tingkat pendidikan terakhir, responden berpendidikan sarjana yaitu $17,8 \%$ atau 8 orang, serta responden berpendidikan magister sebesar $82,2 \%$ atau 37 orang. Hal ini memperlihatkan bahwa responden yang terpilih dalam penelitian ini dapat memiliki tingkat pendidikan yang bervariasi dan cukup tinggi, sehingga bisa memahami isi dan kuesioner yang diberikan

Berdasarkan masa kerja mayoritas responden memiliki masa kerja $>10$ tahun atau $31 \%$. Hal ini memperlihatkan bahwa mayoritas auditor memiliki pengetahuan dan pengalaman yang memadai terkait variabel yang akan diteliti, serta sudah mengetahui kondisi terkait persoalanpersoalan pada organisasi tersebut.

\section{Analisis Statistik motivasi terhadap kinerja auditor}

\section{Analisis Deskriptif Variabel}

Kuesioner penelitian yang telah terkumpul kemudian ditabulasi dengan tujuan analisis data. Adapun data yang ditabulasi adalah semua tanggapan responden atas setiap pertanyaan dalam kuesioner yang melibatkan dua variabel yaitu motivasi (X1) dan kinerja auditor (Y). Variabel terukur menggunakan skala likert 5 tingkatan. Hasil tabulasi data kemudian diolah menggunakan program Statical Product \& Service Solution (SPSS 22.0) untuk mendapatkan 
statistik deskriptif yang menunjukkan nilai minimum, maksimum, rata-rata dan standar deviasi dari masing-masing variabel. Statistik deskriptif variabel-variabel yang digunakan dalam penelitian ini disajikan pada tabel berikut.

Tabel 2 Descriptive Statistics

\begin{tabular}{|l|r|r|r|r|r|}
\hline & \multicolumn{1}{|c|}{$\mathrm{N}$} & \multicolumn{1}{|c|}{ Minimum } & Maximum & \multicolumn{1}{c|}{ Mean } & \multicolumn{1}{|c|}{ Std. Deviation } \\
\hline X3.1 & 45 & 4 & 5 & 4,42 &, 499 \\
X3.2 & 45 & 4 & 5 & 4,53 &, 505 \\
X3.3 & 45 & 4 & 5 & 4,51 &, 506 \\
X3.4 & 45 & 2 & 5 & 4,42 &, 621 \\
X3.5 & 45 & 4 & 5 & 4,62 &, 490 \\
Motivasi & 45 & 3,60 & 5,00 & 4,5022 &, 37567 \\
Valid N (listwise) & 45 & & & & \\
\hline
\end{tabular}

Sumber. Hasil olah data dengan SPSS, 2019

Berdasarkan tabel 2 diatas, nilai minimum, maksimum, rata-rata (mean) dan standar deviasi dapat diketahui dari jawaban responden atas masing-masing pertanyaan kuesioner. Secara rinci statistik deskriptif masing-masing variabel dijelaskan sebagai berikut. :

Variabel motivasi (X1) memiliki nilai minimum (persepsi terendah responden) sebesar 3,60, sedangkan nilai maksimum (persepsi tertinggi responden) terhadap variabel motivasi kerja sebesar 5 dan nilai rata-rata (mean) sebesar 4,50 serta standar deviasi adalah 0,37. Variabel motivasi terdiri dari 5 pertanyaan pada skala likert 5 poin. Hal ini mengindikasikan bahwa persepsi auditor pada inspektorat terhadap variabel motivasi kerja relatif tinggi.

Nilai rata-rata (mean) pada variabel motivasi kerja yaitu 4.50 dengan standar deviasi 0,37 hal ini menunjukkan bahwa secara umum motivasi kerja auditor oada inspektorat Provinsi Sulawesi Selatan dengan indikator yakni kesungguhan dalam bekerja, mukai pekerjaan yang menantang, selalu ingin maju. menetapkan tujuan kerja. dan kepuasan terhadap pekerjaan dinilai cukup baik.

Untuk indikator kesungguhan dalam bekerja mempunvai nilai rata-rata (mean) sebanyak 4,42 dengan standar deviasi 0,499 angka ini berada pada kategori baik. Hasil penelitian menunjukkan secara rata-rata responden menyatakan setuju atau mengindikasikan persepsi auditor mengenai variabel motivasi cukup tinggi. Artinya auditor pada inspektorat provinsi Sulawesi selatan telah mencoba dengan sungguh-sungguh untuk meningkatkan kinerja dalam proses pemeriksaan.

Untuk indikator menyukai pekerjaan yang menantang mempunyai nilai rata- rata (mean) sebanvak 4.53 dengan standar deviasi 0,505 angka ini berada pada kategori baik. Hasil penelitian menunjukkan secara rata-rata responden menyatakan setuju atau mengindikasikan persepsi auditor mengenai variabel motivasi cukup tinggi. Artinya auditor pada lnspektorat 
Provinsi Sulawesi Selatan menikmati tantangan yang sulit dalam menjalankan proses pemeriksaan .

Untuk indikator selalu ingin maju mempunvai nilai rata-rata (mean) sebanyak 4,51 dengan standar deviasi 0,506 angka ini berada pada kategori baik. Hasil penelitian menunjukkan secara rata-rata responden menyatakan setuju atau mengindikasikan persepsi auditor mengenai variabel motivasi cukup tinggi. Artinva auditor pada lnspektorat Provinsi Sulawesi Selatan selalu ingin tahu bagaimana kemajuan yang dicapai dalam menjalankan tugas.

Untuk indikator penetapan tujuan kerja mempunyai nilai rata-rata (mean) sebanyak 4,42 dengan standar deviasi 0,621 angka ini berada pada kategori baik. Hasil penelitian menunjukkan secara rata-rata resoonden menyatakan setuju atau mengindikasikan persepsi auditor mengenai variabel motivasi cukup tinggi. Artinya auditor pada lnspektorat Provinsi Sulawesi Selatan suka menetapkan tujuan kerja serta pencapaian yang realistis dalam melaksanakan suatu pekeriaan.

Untuk indikator kepuasan terhadap pekerjaan mempunyai nilai rata-rata (mean) sebanyak 4.62 dengan standar deviasi 0.490 angka ini berada pada kategori baik. Hasil penelitian menunjukkan secara rata-rata responden menyatakan setuju atau mengindikasikan persepsi auditor mengenai variabel motivasi cukup tinggi. Artinya auditor pada lnspektorat Provinsi Sulawesi Selatan.

Tabel 3

\begin{tabular}{|l|r|r|r|r|r|}
\hline & D & Minimum & Maximum & Mean & Std. Deviation \\
\hline Y.1 & 45 & 2 & 5 & 4,29 &, 695 \\
Y.2 & 45 & 4 & 5 & 4,38 &, 490 \\
Y.3 & 45 & 4 & 5 & 4,33 &, 477 \\
Y.4 & 45 & 4 & 5 & 4,31 &, 468 \\
Y.5 & 45 & 4 & 5 & 4,38 &, 490 \\
Y.6 & 45 & 4 & 5 & 4,42 &, 499 \\
Y.7 & 45 & 4 & 5 & 4,44 &, 503 \\
Kinerja Auditor & 45 & 3,83 & 5,00 & 4,3469 &, 32892 \\
Valid N (listwise) & 45 & & & & \\
\hline
\end{tabular}

Variabel kinerja auditor (Y) memiliki nilai minimum (persepsi terendah responden) sebesar 3,83 nilai maksimum (persepsi tertinggi responden) terhadap variabel kinerjan sebesar 5 dan nilai rata-rata (mean) sebesar 4,34 serta standar deviasi adalah 0,32 Variabel kinerja auditor terdiri dari 7 pertanyaan pada skala likert 5 poin. Hal ini mengindikasikan bahwa persepsi auditor pada inspektorat terhadap variabel kinerja relatif tinggi.

Kinerja auditor (Y) yang merupakan hasil kerja yang dicapai seorang auditor dalam melaksanakan penugasan pemeriksaan (examination) secara objektif atas laporan keuangan suatu organisasi. Variabel kinerja auditor dalam penelitian inidiukur dengan menggunakan 
instrument yang dkembangkan oleh Fuad Mas'ud (2004) dengan indikator kemampuan bekerjasama, kualitas pekerjaan, kemampuan tekhnis, inisiatif, semangat, daya tahan/kehandalan, kuantitas pekerjaan.

Untuk indikator kuantitas pekerjaan mempunyai nilai rata-rata (mean) sebanyak 4.29 dengan standar deviasi 0.695 angka ini berada pada kategori baik. Hasil penelitian menunjukkan secara rata-rata responden menyatakan setuju atau mengindikasikan persepsi auditor mengenai variabel kineria auditor cukup tinggi artinya kuantitas kerja auditor telah sesuai dengan tanggung jawab yang diberikan.

Untuk indikator daya tahan/kehandalan mempunyai nilai rata-rata (mean) sebanyak 4.38 dengan standar deviasi 0.490 angka ini berada pada kategori baik. Hasil penelitian menunjukkan secara rata-rata responden menyatakan setuju atau mengindikasikan persepsi auditor mengenai variabel kinerja auditor cukup tinggi Artinya auditor dianggap handal karena dapat melakukan efisiensi terhadap anggaran waktu yang telah disusun.

Untuk indikator kualitas pekerjaan mempunyai nilai rata-rata (mean) sebanyak 4.33 dengan standar deviasi 0.477 angka ini berada pada kategori baik. Hasil penelitian menunjukkan secara rata-rata responden menyatakan setuju atau mengindikasikan persepsi auditor mengenai variabel kineria auditor cukup tinggi. Artinya standar kualitas kerja auditor melebihi standar resmi yang ada.

Untuk indikator kemampuan tekhnis mempunyai nilai rata-rata (mean) sebanyak 4,31 dengan standar deviasi 0,468 angka ini berada pada kategori baik. Hasil penelitian menunjukkan secara rata-rata responden menyatakan setuju atau mengindikasikan persepsi auditor mengenai variabel kinerja auditor cukup tinggi. Artinya kemampuan auditor dalam melakukan pekerjaan utama sudah cukup baik.

Untuk indikator ketepatan waktu mempunyai nilai rata-rata (mean) sebanyak 4.38 dengan standar deviasi 0.490 angka ini berada pada kategori baik. Hasil penelitian menunjukkan secara rata-rata responden menyatakan setuju atau mengindikasikan persepsi auditor mengenai variabel kinerja auditor cukup tinggi .Artinya auditor dapat melaksanakan pekerjaan tepat waktu.

Untuk indikator kualitas pekerjaan mempunyai nilai rata-rata (mean) sebanyak 4,42 dengan standar deviasi 0,499 angka ini berada pada kategori baik.Hasil oenelitian menuniukkan secara rata-rata resoonden menvatakan setuiu atau mengindikasikan persepsi auditor mengenai variabel kinerja auditor cukup tinggi. Artinya pengetahuan auditor dalam melaksanakan pekerjaan cukup baik.

Untuk indikator kreativitas mempunyai nilai rata-rata (mean) sebanyak 4,44 dengan 
standar deviasi 0,503 angka ini berada pada kategori baik. Hasil penelitian menunjukkan secara rata-rata responden menyatakan setuju atau mengindikasikan persepsi auditor mengenai variabel kinerja auditor cukup tinggi artinya kreativitas auditor dalam melaksanakan pekerjaannya cukup baik.

\section{Uji Asumsi Klasik}

Sebelum analisis regresi dapat diinterpretasikan, terlebih dahulu dilakukan pengujian asumsi klasik yang meliputi uji normalitas, uji multikolinieritas dan uji heteroskedastisitas. Uji asumsi klasik tersebut adalah sebagai berikut.

\section{a. Uji Normalitas}

Uji normalitas dilakukan dengan melihat penyebaran data pada sumber diagonal pada grafik Normal P-P Plot of regression standardized residual (metode grafik) atau dengan uji one sample kolmogrov smirnov (Ghozali, 2011). Dasar pengambilan keputusan dilakukan berdasarkan probabilitas (Asymtotic Significance), yaitu :

a. Jika probabilitas $>0,05$ maka distribusi dan model regresi adalah normal.

b. Jika probabilitas $<0,05$ maka distribusi dan model regresi adalah tidak berdistribusi secara normal

Tabel 4

\section{Hasil Uji Normalitas}

One-Sample Kolmogorov-Smirnov Test

\begin{tabular}{|ll|r|}
\hline & & 1_Absol ut \\
\hline Normal Parameters & & \\
& & 45 \\
Most Extreme Differences & Mean &, 0437 \\
& Std. Deviation &, 03011 \\
& Absolute &, 106 \\
& Positive &, 106 \\
Test Statistic & Negative &,- 083 \\
Asymp. Sig. (2-tailed) & &, 106 \\
\hline
\end{tabular}

a. Test distribution is Normal.

b. Calculated from data.

c. Lilliefors Significance Correction.

d. This is a lower bound of the true significance.

Gambar 1 di bawah ini adalah grafik normal P-P Plot of regression standardized residual dan menunjukkan titik-titik data menyebar mengikuti garis normal. Hal ini berarti data yang digunakan untuk menganalisa pengaruh dari variabel dependen terhadap variabel independen memiliki data normal atau mendekati normal, dengan demikian persamaan regresi linear dalam penelitian ini dinyatakan memenuhi asumsi klasik normalitas data 


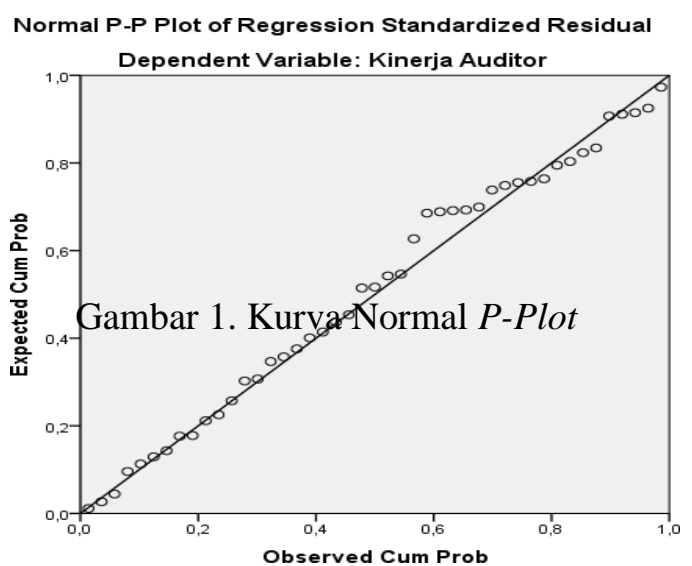

\section{b. Uji Heteroskedasitas}

Uji heteroskedasitas dilakukan dengan analisis grafik scatterplots. Gambar dibawah ini memperlihatkan tidak ada pola yang jelas, yaitu titik-titik menyebar di atas dan di bawah angka 0 (nol) pada sumbu Y. Ini berarti tidak terjadi heteroskedasitas.

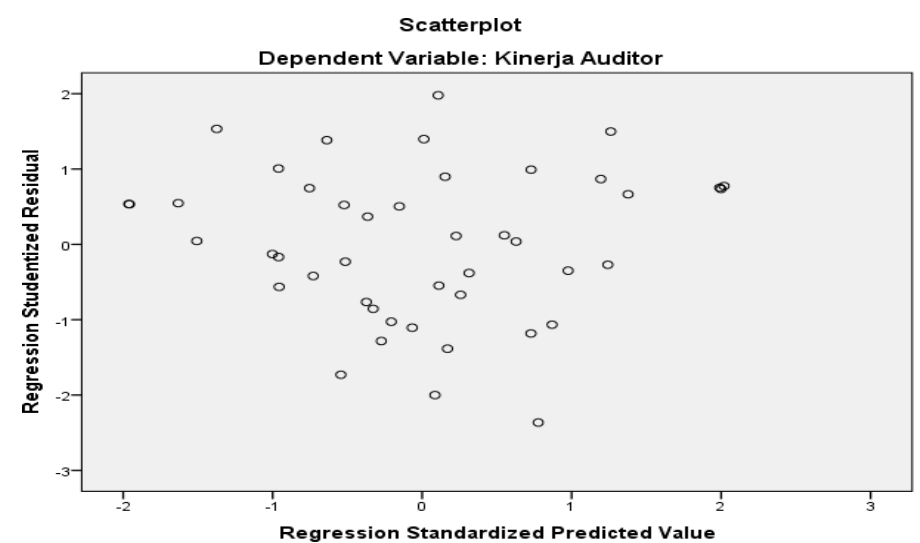

\section{c. Uji Multikolinearitas}

Uji multikolinearitas dilakukan untuk menguji ada atau tidaknya korelasi antar variabel bebas (independen) dalam model regresi. Uji multikolinearitas dapat dilakukan dengan cara melihat Variane Inflation Factor (VIF) dan nilai tolerance. Jika nilai VIF $\leq 10$ atau nilai $\geq 0,1$ maka bebas multikolinearitas. Hasil pengujian multikolinearitas dapat dilihat pada tabel berikut ini.

Tabel 5 Hasil Uji Multikolinearitas

\begin{tabular}{|c|c|c|}
\hline \multirow[b]{2}{*}{ Model } & \multicolumn{2}{|c|}{ Collinearity Statistics } \\
\hline & Tolerance & VIF \\
\hline (Constant) & & \\
\hline Motivasi & ,746 & 1,341 \\
\hline
\end{tabular}

Dependent Variable: Kinerja Auditor

Berdasarkan tabel diatas, dapat dilihat bahwa nilai tolerance $\geq 0,1$ dan nilai VIF $\leq 10$. Dengan demikian tidak terjadi Multikolinearitas pada semua variabel independen dalam penelitian ini. 


\section{Uji Hipotesis}

Pengujian hipotesis dilakukan setelah pengujian asumsi klasik dan diperoleh kesimpulan bahwa model sudah dapat digunakan untuk pengujian analisa regresi. Pengujian hipotesis menggunakan pengujian analisis koefisien determinasi $\left(\mathrm{R}^{2}\right)$

\section{Uji Koefisiensi Determinasi $\left(\boldsymbol{R}^{2}\right)$}

Uji koefisien determinasi $\left(\mathrm{R}^{2}\right)$ digunakan untuk menguji seberapa besar pengaruh variabel independen terhadap variabel dependen. Tabel berikut memperlihatkan hasil uji koefisien determinan sebelum dan sesudah dilakukan interaksi

\section{Tabel 6}

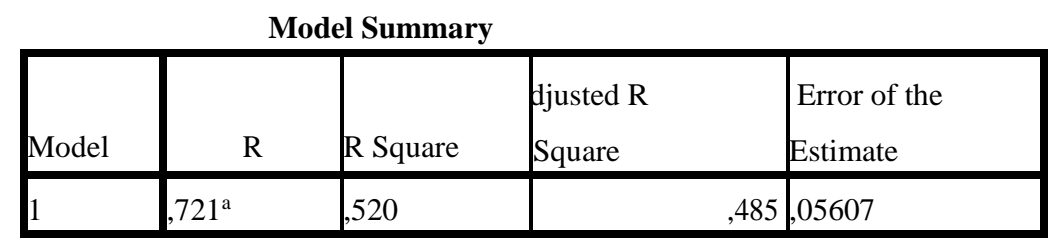

a. Predictors: (Constant), Motivasi

Hasil uji koefisien sebelum adanya interaksi seperti yang terlihat pada tabel 5 menunjukkan nilai koefisien korelasi berganda (R) antara variabel motivasi dan kinerja auditor adalah sebesar 0,721 Semakin mendekati 1 maka semakin kuat hubungannya. Nilai koefisien determinasi $\left(\mathrm{R}^{2}\right)$ adalah sebesar 0,520 Jadi 52\% variabel dependen kinerja auditor dijelaskan oleh variable independen motivasi sedangkan sisanya $48 \%$ (100\% - 52\%) dijelaskan oleh variabel lain di luar variabel yang digunakan dalam penelitian ini.

\section{a. Uji F}

Pengujian adanya pengaruh variabel independen secara simultan terhadap variabel dependen dilakukan dengan melihat nilai $\mathrm{F}$ sebagaimana dapat dilihat pada tabel ANOVA berikut ini. Pengujian menggunakan tingkat keyakinan $95 \%, \alpha=5 \%$, df 1 (jumlah variabel 1) $=2-1=1$, dan df $2(n-k)$ atau 45-2 = 43 (n adalah jumlah kasus dan k adalah jumlah variabel), hasil diperoleh untuk $\mathrm{F}$ tabel sebesar 4.07

Tabel 7 Uji F (Anova)

ANOVA $^{a}$

\begin{tabular}{|l|r|r|r|l|l|}
\hline Model & Sum of Squares & Df & Mean Square & F & Sig. \\
\hline $1 \quad$ Regression &, 140 & 3 &, 047 & 14,803 &, $000^{\mathrm{b}}$ \\
Residual &, 129 & 41 &, 003 & & \\
Total &, 268 & 44 & & & \\
\hline
\end{tabular}

a. Dependent Variable: Kinerja Auditor 
Predictors: (Constant), Motivasi

Berdasarkan tabel 6 terlihat bahwa $\mathrm{F}$ hitung adalah 14,803 dengan sig 0,00 dan nilai $\mathrm{F}$ tabel = 4,07 dengan derajat kebebasan 5\%, maka dapat disimpulkan bawa $\mathrm{F}$ hitung $>\mathrm{F}$ tabel, hal ini berarti terdapat pengaruh yang nyata antara motivasi dengan kinerja auditor. Berdasarkan hasil uji yang telah dilakukan, maka hasil pengujian hipotesis dapat disimpulkan sebagai berikut.

\section{Pengaruh motivasi terhadap kinerja auditor}

Berdasarkan coefficients tabel 7, uji t variabel motivasi menunjukkan nilai t hitung sebesar 3,516 sedangkan nilai t tabel dengan degree of freedom (df) $n-k=45-2-1=42$ dan $\alpha=5 \%$ (dua arah) maka menunjukkan nilai $\mathrm{t}$ tabel $=2,018$. Jadi $\mathrm{t}$ hitung 3,516 $>\mathrm{t}$ tabel 2,018. Hasil uji signifikansi juga memperlihatkan nilai probabilitas variabel motivasi sebesar 0,001 . Dengan demikian hipotesis 1 yang menyebutkan motivasi mempunyai pengaruh yang signifikan terhadap kinerja auditor, diterima.

\section{SIMPULAN}

Motivasi berpengaruh terhadap kinerja auditor inspektorat provinsi Sulawesi selatan. Motivasi merupakan dava dorong baai seseorang untuk memberikan kontribusi yang sebesar mungkin demi keberhasilan organisasi mencapai tuiuannva. Hasil penelitian ini mendukung Goal Setting Theory yang menjelaskan hubungan antara tujuan yang ditetapkan dengan prestasi kerja (kinerja). konsep dasar teori ini adalah seseorang yang memahami tujuan (apa yang diharapkan organisasi kepadanya) akan mempengaruhi perilaku kerjanya.

\section{DAFTAR PUSTAKA}

Akbar, Moch Nizar. 2015. Pengaruh independensi dan profesionalisme terhadap kinerja auditor. Jurnal ekonomi dan bisnis Vol 3 No 2

Arens, Alvin A., Elder, dan Beasley. 2008. Auditing dan jasa assurance pendekatan terintegrasi jilid 1. Edisi 12. Jakarta : Erlangga

Azhar, Al. 2013. Pengaruh konflik peran, ketidakjelasan peran, kesan ketidakpastian lingkungan, locus of control dan motivasi kerja terhadap kinerja auditor studi empiris pada kantor akuntan public di pekanbaru, padang dan batam., jurnal ekonomi, universitas riau kampus bina widya volume 21 , nomor 4

Fuad Mas'ud, 2004, "Survai Diagnosis Organisasional”, Badan Penerbit Universitas Diponegoro, Semarang

Hariandja, Marihot. T.E. 2009. Manajemen Sumber Daya Manusia Pengadaan, Pengembangan, Pengkompensasian, dan Peningkatan Produktivitas Pegawai. Jakarta : PT Bumi Aksara.

Locke. 1990. "A Theory Of Goal Setting Theory And Task Performance". The Academy Of Management Review. 
Marita, dan Gultom, Yossy Purnama Sari. 2018. Pengaruh Profesionalisme, Etika Profesi, Independensi, Motivasi dan Komitmen Organisasi Terhadap Kinerja Auditor Internal (Studi Kasus Pada PT Perkebunan Nusantara IV Medan). Universitas Pembangunan Nasional Veteran Jakarta. Jurnal penelitian ekonomi dan akuntansi, volume III Nomor 1.

Mangkunegara, 2009. Manajemen sumber daya manusia. Remaja Moeheriono. 2012.Pengukuran kinerja berbasis kompetensi. Jakarta : Raja Grafindo Persada.

Mulyadi, 2008. Sistem akuntansi, Jakarta : Salemba Empat. , 2013. Sistem Akuntansi, Edisi Ketiga, Cetakan Keempat, Salemba Empat, Jakarta.

Panjaitan, Anton dan Jatmiko, Bambang. 2014. Pengaruh Motivasi, Stress, dan Rekan Kerja Terhadap Kinerja Auditor (Studi Empiris Pada Kantor Akuntan Publik di DKI Jakarta). Jurnal Bisnis dan Ekonomi, Volume 5 Nomor 1, Hal 1 - 18

Permana, Yockie. 2016. Analisis pengaruh motivasi, stress, dan rekan kerja terhadap kinerja auditor di kantor badan pengawas keuangan dan pembangunan riau dan sumatera utara.

Robbins SP, dan Judge. 2008. Perilaku organisasi Buku 2, Jakarta : Salemba Empat. Hal 256. . 2015. Perilaku organisasi Buku 2, Jakarta : Salemba Empat

Samsudin, Sadili. 2010. Manajemen Sumber Daya Manusia. Bandung Pustaka Setia. Sanjiwani, Desak Made Putri dan I Gede Suparta Wisadha. 2016. Pengaruh Locus Of Control, Gaya Kepemimpinan, dan Komitmen Organisasi Pada Kinerja Auditor Kantor Akuntan Public. Universitas Udayana. E Jurnal akuntansi universitas udayana Volume 14 Nomor 2, hal 920-947

Sondang P, Siagian. 2009. Kiat meningkatkan produktivitas kerja. Jakarta: PT Rineka Cipta

Wibowo. 2014. Manajemen kinerja. Edisi keempat. Jakarta : Rajawali Pers Widhi.

Wirawan. 2009. Evaluasi Kinerja Sumber Daya Manusia Teori Aplikasi dan

Penelitian. Jakarta. Penerbit : Salemba Empat

http://www.inspektoratsulsel.id

http://sipp.pn-makassar.go.statistik/statistik_perkara 